

\title{
POTENSI PRODUKSI GELATIN CEKER AYAM SEBAGAI UPAYA \\ PEMENUHAN GELATIN DALAM NEGERI GUNA \\ MEWUJUDKAN KESEJAHTERAAN \\ MASYARAKAT INDONESIA
}

(Rifqi Dhiemas Aji, Annas) (Universitas Gadjah Mada)

(rifqi.dhiemas.a@mail.ugm.ac.id)

\begin{abstract}
Abstrak
Perubahan zaman yang semakin menuju modern menjadikan perubahan lifestyle yang sangat cepat. Akan tetapi, pemenuhan kebutuhan gelatin di Indonesia masih 100\% impor dan sumber bahan baku belum diketahui kehalalannya. Padahal, sumber bahan baku seperti ceker ayam tersedia banyak. Namun, belum dapat dimanfatkan secara optimal. Gelatin ceker ayam tidak kalah bila dibandingkan dengan gelatin dari kulit ruminansia. Gelatin ceker ayam memiliki viskositas dan kekuatan gel yang sesuai dengan standar gelatin yaitu kekuatan gel sebesar 50-300 g Bloom, dan viskositas 1,5-7.5 cP. Studi ini bertujuan untuk mengetahui potensi ceker ayam sebagai bahan baku gelatin di Indonesia sebagai alternatif utama pengolahan hasil ikutan pemotongan ayam dalam upaya pemenuhan kebutuhan gelatin di Indonesia serta dapat memaksimalkan potensi hasil ikutan pemotongan ayam untuk menghasilkan manfaat dan daya guna yang lebih luas dari sebelumnya. Penulisan ini menggunakan metode deskriptif. Data yang dikumpulkan berupa kata-kata (wawancara), dan data stastistik sehingga mempermudah penulis untuk membuat hubungan antar obyek kajian. Dengan memperhatikan populasi ayam yang menghasilkan ceker ayam yang melimpah, pengolahan gelatin dapat menjadi alternatif utama dalam pengolahan ceker ayam. Data populasi ayam ras pedaging sebanyak 1.592.669.402 ekor, dan asumsi bobot potong 1,5 kg sementara persentase ceker sekitar $4,57 \%$ dan rendemen sekitar $10,7 \%$ maka potensi produksi gelatin sebesar 11.681.991,16 kg. Hal ini dapat diperoleh dari bahan lokal di Indonesia tanpa mengimpor.
\end{abstract}

Keyword: Gelatin, Ceker Ayam, Rendemen 


\section{BAB I \\ PENDAHULUAN}

a. Pendahuluan

Perubahan zaman yang semakin menuju modern menjadikan perubahan lifestyle yang sangat cepat. Banyak produk makanan menggunakan gelatin sebagai bahan tambahan. Diperkirakan sekitar 59\% gelatin yang telah dibuat di seluruh dunia digunakan untuk memproduksi makanan, 31\% diaplikasikan pada produk farmasi, $2 \%$ dimanfaatkan untuk industri fotografi, dan sekitar $8 \%$ diaplikasikan dalam bidang lain (GME, 2015). Ditambah lagi gelatin memiliki kandungan nutrien yang baik. Gelatin mengandung asam amino seperti 14\% hidroxyprolin, $16 \%$ prolin, $26 \%$ glisin, kandungannya tergantung dari bahan mentahnya (Ockerman dan Hansen, 2000). Hal ini mengakibatkan kebutuhan gelatin meningkat melihat manfaatnya yang begitu banyak.

Kebutuhan gelatin di Indonesia semakin meningkat setiap tahunnya. Impor gelatin tahun 2005 sampai 2007 berturut-turut sebesar $596.933 \mathrm{~kg}, 1.094 .195 \mathrm{~kg}$, dan $2.115 .741 \mathrm{~kg}$ yang berasal dari berbagai negara (Perancis, Jepang, India, Brazil, Jerman, Cina, Argentina, dan Australia) untuk memenuhi kebutuhan dalam negeri (Said et al., 2011b). Sebuah ironi dengan kebutuhan gelatin semakin hari semakin meningkat, namun pemenuhan gelatin dalam negeri masih tergantung dari impor. Wajar bila kebutuhan gelatin tinggi melihat keunikan dan sifat fungsionalnya yang luas untuk aplikasi dalam berbagai industri dan juga untuk meningkatkan kandungan protein pada bahan pangan. Namun, masyarakat Indonesia tidak mengerti mengenai produk maupun manfaat gelatin. Produk gelatin yang banyak beredar di Indonesia berbentuk kapsul atau sudah dalam bentuk aplikasi makanan. Hal ini dikarenakan kebutuhan gelatin dalam negeri masih dipenuhi dari impor sehingga masyarakat tidak familiar dengan gelatin.

Penduduk Indonesia mayoritas adalah muslim sehingga masalah kehalalan gelatin menjadi utama. Pertimbangannya asal tulang atau kulit yang digunakan sebagai bahan baku gelatin sering tidak dicantumkan sumber jenis hewan ternak yang digunakan. Di luar negeri hampir 100\% gelatin terbuat dari tulang dan kulit babi. Tidak dapat kita pungkiri bahwa pembuatan gelatin dari babi memang jauh 
lebih murah dibandingkan dengan gelatin yang berbahan baku kulit atau tulang ternak lainnya. Kontribusi gelatin dunia dipasok dari $44 \%$ gelatin yang berasal dari babi dan $56 \%$ berasal dari tulang dan kulit sapi. Hal inilah yang menimbulkan keraguan kehalalan pada masyarakat Indonesia bila pemenuhan gelatin masih tergantung impor.

Cita-cita bangsa Indonesia untuk mewujudkan kesejahteraan masyarakat yang tertuang pada UUD 1945 dan UU No 11 tahun 2009 tentang kesejahteraan sosial. Selain itu, demi mewujudkan ketahanan pangan yang tertuang dalam Peraturan Pemerintah Republik Indonesia Nomor 68 Tahun 2002 Tentang Ketahanan Pangan menyebutkan bahwa ketahanan pangan adalah kondisi terpenuhinya pangan bagi rumah tangga yang tercermin dari tersedianya pangan yang cukup, baik jumlah maupun mutunya, aman, merata dan terjangkau. Ketergantungan akan impor harus ditanggulangi dengan mencari solusi alternatif.

Pemanfaatan ceker ayam sebagai bahan baku pembuatan gelatin cukup menjanjikan, dimana saat ini ceker ayam hanya dimanfaatkan sebagai bahan campuran sup dan pembuatan kerupuk kulit kaki ayam. Sampai saat ini bahan baku yang banyak digunakan untuk produksi industri gelatin adalah tulang sapi, kulit sapi dan kulit babi. Sumber bahan baku gelatin yang saat ini telah banyak diteliti dan dilaporkan antara lain berasal dari tulang dan kulit ikan, tulang domba serta cakar ayam (Said et al., 2011a). Gelatin merupakan protein yang didapat dari proses pengolahan kolagen dari kulit, jaringan ikat, dan tulang hewan.

Pembuatan gelatin dari ceker ayam diluar negeri memang belum populer terutama di Eropa dan Amerika karena tidak mempertimbangkan kehalalan. Namun, telah ada beberapa penelitian seperti Widyasari dan Rawdkuen (2014), Rahman dan Jamalulail (2012), Gómez-Guillénet et al., (2011), Nik Aisyah et al., (2014) bahwa ceker ayam dapat dijadikan bahan baku gelatin. Potensi cakar ayam menjadi bahan baku gelatin sangat besar. Di Indonesia, banyak penelitian yang telah dilakukan mengenai cakar ayam menjadi gelatin seperti Sompie et al., (2015), Munda (2013), Puspitasari et al., (2013).

Ceker ayam dapat menggantikan bahan baku dari kulit babi dalam jumlah ketersediaan bahan baku. Gelatin ceker ayam tidak kalah bila dibandingkan dengan gelatin dari kulit ruminansia. Rares et al., (2017) dalam penelitiannya 
memaparkan bahwa rataan viskositas gelatin ceker ayam berkisar antara 4,86 $5,11 \mathrm{cP}$, rataan kekuatan gel gelatin ceker ayam berkisar antara 62,30 - 68,71 g Bloom. Hal ini sudah sesuai dengan standar gelatin yaitu kekuatan gel sebesaar 50 - 300 g Bloom, dan viskositas 1,5 - 7.5 cP (GMIA, 2012). Populasi ayam tahun 2016 mencapai 1.592.669.402 ekor ayam ras pedaging, 162.051.262 ekor ayam ras peletur, 298.672.970 ekor ayam buras (Direktorat Jenderal Peternakan dan Kesehatan Hewan, 2016). Populasi yang sangat besar, sehingga akan menghasilkan hasil ikutan pemotongan ayam khususnya ceker yang melimpah. Setiap tahunnya ceker ayam yang dihasilkan belum dimanfaatkan secara optimal. Studi ini bertujuan untuk mengetahui potensi bahan baku lokal gelatin di Indonesia sebagai alternatif utama pengolahan hasil ikutan pemotongan ternak dalam upaya pemenuhan kebutuhan gelatin di Indonesia serta dapat memaksimalkan potensi hasil ikutan pemotongan ternak untuk menghasilkan manfaat dan daya guna yang lebih luas dari sebelumnya.

\section{b. Perumusan Masalah}

Gelatin sebagai bahan yang sering digunakan di Indonesia dalam makanan maupun obat-obatan. Akan tetapi, pemenuhan kebutuhan gelatin di Indonesia masih 100\% impor. Selain itu, gelatin impor dari aspek kehalalan yang masih memiliki keraguan bagi masyarakat Indonesia. Padahal, sumber bahan baku seperti ceker ayam tersedia banyak. Namun, belum dapat dimanfaatkan secara optimal. Berdasarkan hal tersebut perlu adanya solusi dengan mempopulerkan industri gelatin dengan melihat potensi bahan baku ceker ayam yang tersedia sehingga dapat memenuhi kebutuhan gelatin di Indonesia.

\section{c. Tujuan Penulisan}

Tujuan dari karya tulis ini adalah memberikan wawasan, gambaran serta peluang gelatin apabila diproduksi di Indonesia. Selain itu, dapat memberikan solusi dengan mempopulerkan industri gelatin dengan melihat potensi bahan baku lokal yang tersedia seperti ceker ayam sehingga dapat memenuhi kebutuhan gelatin di Indonesia. Memberikan gambaran potensi ceker ayam agar bermanfaat lebih bagi kelangsungan hidup. 
d. Manfaat Penulisan

Penulisan ini memberi manfaat antara lain :

1. Bagi Penulis

- Memberikan wawasan dan pengalaman bagi penulis dalam menyusun karya tulis ilmiah.

- Dapat menerapkan metode ilmiah seperti yang dilakukan oleh ilmuwan dalam melakukan penulisan.

- Membuat penulis lebih peka terhadap pemanfaatan bahan-bahan yang belum dimanfaatkan secara optimal menjadi suatu yang lebih bermanfaat.

- Membuat penulis lebih kreatif dalam mencari alternatif pemanfaatan bahan-bahan hasil ikutan pemotongan ayam.

2. Bagi Masyarakat

- Dapat menyumbangkan ide pengolahan hasil ikutan pemotongan ayam dalam upaya pemenuhan kebutuhan gelatin di Indonesia.

- Dapat memberikan gambaran luas tentang kebutuhan dan upaya untuk memenuhi gelatin di Indonesia. Harapannya Indonesia dapat memproduksi dan membuka lapangan pekerjaan baru yang luas.

- Mengurangi keraguan kehalalan produk gelatin di lingkungan masyarakat serta mendapat jaminan kehalalan apabila gelatin dapat di produksi di Indonesia. 


\section{BAB II}

\section{TINJAUAN PUSTAKA}

a. Pemanfaatan ceker ayam

Ceker ayam merupakan salah satu hasil ikutan pemotongan ayam yang memiliki potensi yang bagus. Ceker ayam terdiri dari tulang dan kulit yang memiliki kandungan yang baik. Ditinjau dari komposisi kimianya, kulit kaki ayam mengandung sekitar 22\% protein kasar; 5,50\% lemak; 3,5\% abu; $64 \%$ air; dan 3\% substansi lain (Taufik, 2011). Sementara bahan pengisi pada tulang adalah protein dan garam-garam mineral, seperti kalsium fosfat 58,3\%; kalsium karbonat 1,0\%; magnesium fosfat 2,1\%; kalsium florida $1,9 \%$ dan protein 30,6\%. Tulang mengandung kurang lebih 50\% air dan 15\% sumsum merah dan kuning. Sumsum terdiri dari lemak sebesar 96\% (Saleh, 2004).

Ceker ayam merupakan bagian dari tubuh ayam yang, terdiri atas komponen kulit, tulang, otot, dan kolagen. Kolagen dalam ceker ayam adalah 9,07\%. Komposisi asam amino dari ceker ayam ditemukan 30\% dari total asam amino residu yang terdiri $30,17 \%$ glycine, $11,7 \%$ proline dan $10-12,7 \%$ alanine dan glutamic acid (Liu et al., 2001), komposisi kimia ceker ayam dapat tersaji dalam Tabel 1. Kandungan kolagen yang terkandung dalam ceker ayam memiliki potensi untuk menjadi gelatin.

Tabel 1. Komposisi kimia ceker ayam

\begin{tabular}{cc}
\hline Kandungan & Proporsi $(\%)$ \\
\hline Air & $62,05 \pm 0,60$ \\
Lemak & $12,04 \pm 0,44$ \\
Protein & $17,42 \pm 0,73$ \\
Kolagen & $9,07 \pm 0,18$ \\
Abu & $5,98 \pm 0,37$ \\
\hline & Sumber: Liu et al. $(2001)$
\end{tabular}

Ockerman dan Hansen (2000) menyatakan bahwa hidrolisis terkontrol dibutuhkan untuk mengubah kolagen yang memiliki berat molekul kolagen berkisar 345.000 Da sampai 360.000 Da, menjadi gelatin yang memiliki berat molekul berkisar 10.000 Da sampai $65.000 \mathrm{Da}$, dan terdapat beberapa kasus yang mencapai berat molekul 250.000 Da. Tropokolagen yang diekstraksi mengalami proses hidrolisis, yang terjadi pada saat perendaman dalam larutan asam, di mana 
ikatan hidrogen dan ikatan silang kovalen rantai-rantai tropokolagen diputus, sehingga menghasilkan tropokolagen triple helix yang berubah menjadi rantairantai $\alpha$ yang larut dalam air atau disebut gelatin (Djabourov et al., 1993).

Potensi ceker ayam memiliki peran yang sangat besar untuk mendukung ketahanan pangan nasional. Kaki ayam (tarso metatarsus) merupakan salah satu sisa hasil pemotongan ayam yang dapat dimanfaatkan dan diproses menjadi produk-produk yang akan menghasilkan nilai tambah. Pemanfaatan tulang ayam pada saat ini antara lain sebagai tepung tulang dalam campuran pakan ternak. Nilai tambah yang diperoleh dari pemanfaatan tulang tersebut relatif lebih rendah. Oleh karena itu perlu dicari alternatif lain untuk lebih meningkatkan nilai pada pemanfatan tulang ayam. Pemanfaatan ceker ayam sebagai gelatin diharapkan memberikan nilai tambah yang lebih besar, ceker ayam tersebut dapat diperoleh dari rumah potong ayam.

\section{b. Gelatin}

Menurut Montero dan Gómez-Guillén (2000), gelatin adalah salah satu hidrokoloid yang dapat digunakan sebagai gelling, bahan pengental atau penstabil. Gelatin berbeda dengan hidrokoloid lain, karena kebanyakan hidrokoloid adalah polisakarida seperti karagenan dan pektin, sedangkan gelatin merupakan protein mudah dicerna, mengandung semua asam-asam amino essensial kecuali triptofan. Protein kolagen ini secara ilmiah dapat ditangkap untuk dikonversi menjadi gelatin. Gelatin secara kimiawi diperoleh melalui rangkaian proses hidrolisis kolagen yang terkandung dalam kulit dan tulang. Reaksi yang terjadi adalah:

$$
\begin{array}{llc}
\mathrm{C}_{102} \mathrm{H}_{149} \mathrm{~N}_{31} \mathrm{O}_{38}+\mathrm{H}_{2} \mathrm{O} & \longrightarrow & \mathrm{C}_{102} \mathrm{H}_{151} \mathrm{~N}_{31} \mathrm{O}_{39} \\
\text { Kolagen } & \text { Gelatin }
\end{array}
$$

(Montero dan Gómez-Guillén, 2000)

Prosedur produksi gelatin harus memenuhi persyaratan pemindahan bahan non kolagen tanpa perubahan pada kolagen, mengendalikan hidrolisis kolagen menjadi gelatin agar tidak menimbulkan efek buruk pada hasil akhir dan produk jadi (Manjula et al., 2015). Pemanasan yang dilakukan untuk melarutkan kolagen sekurang-kurangnya $49^{\circ} \mathrm{C}$ atau biasanya pada suhu $60{ }^{\circ} \mathrm{C}$ sampai $70^{\circ} \mathrm{C}$. Gelatin memiliki sifat dapat berubah secara reversible dari bentuk sol ke gel, membengkak atau mengembang dalam air dingin, dapat membentuk film, 
mempengaruhi viskositas suatu bahan, dan dapat melindungi sistem koloid (Montero dan Gómez-Guillén, 2000). Kualitas gelatin dipengaruhi oleh berbagai faktor seperti macam dan mutu bahan mentah, metode perlakuan asam atau basa, cara prosesing, dan kondisi ekstraksi (Ockerman dan Hansen, 2000).

Berdasarkan metode pembuatannya, gelatin dibedakan menjadi gelatin tipe A dan gelatin tipe B (Bosch dan Gielens, 2003). Dalam penelitian (Junianto et al., 2006) pembuatan gelatin tipe A, bahan baku diberi perlakuan perendaman larutan asam sehingga proses ini dikenal dengan sebutan proses asam. Sedangkan dalam pembuatan gelatin tipe B, perlakuan yang diaplikasikan adalah perlakuan basa. Perlakuan dengan basa sering dikenal sebagai proses alkali (Amiruddin, 2007). Meskipun secara umum gelatin mempunyai kegunaan yang hampir sama, namun terdapat perbedaan sifat antara gelatin tipe A dan tipe B (Tabel 2). Barbooti et al. (2008) menyatakan bahwa gelatin tipe A banyak digunakan pada proses pembuatan gelatin dengan bahan baku kulit babi sedangkan gelatin tipe B banyak digunakan untuk proses pembuatan gelatin dengan bahan baku kulit dan tulang sapi.

Tabel 2. Sifat gelatin tipe A dan tipe B

\begin{tabular}{lcc}
\hline \multicolumn{1}{c}{ Sifat } & Tipe A & Tipe B \\
\hline Kekuatan gel (g bloom) & $50-300$ & $50-300$ \\
Viskositas (cP) & $15-75$ & $20-75$ \\
Kadar abu (\%) & $0,30-2,00$ & $0,50-2,00$ \\
pH & $3,50-5,50$ & $5,00-7,50$ \\
Titik isoelektrik & $7,00-9,00$ & $4,70-5,40$ \\
\hline
\end{tabular}

\section{c. Gelatin Ceker Ayam}

Ceker ayam memiliki potensi yang besar untuk dijadikan sebagai sumber gelatin karena kandungan kolagen yang dimiliki yaitu sekitar 9\%. Kolagen ceker ayam banyak mengandung asam amino glycine, asam glutamic, proline dan hydroxyproline (Liu et al., 2011; Hashim et al., 2014). Banyak penelitian yang telah dilakukan mengenai gelatin dari ceker ayam.

Sompie et al., (2015) meneliti tentang pengaruh suhu ekstraksi dan menyimpulkan bahwa gelatin kulit kaki ayam yang diproduksi menggunakan suhu ekstraksi $50^{\circ} \mathrm{C}, 55^{\circ} \mathrm{C}$, dan $60^{\circ} \mathrm{C}$ menghasilkan karakteristik gelatin dengan kualitas 
yang baik karena masih memenuhi standar yang ditetapkan SNI. Viskositas berkisar antara 5,05-5,12 cP dan masih termasuk dalam kisaran standar mutu SNI yaitu antara 2,0-7,5 cP. Produksi gelatin pada penelitian ini menghasilkan kekuatan gel rata-rata pada kisaran 62,44-64,42 g Bloom.

Penelitian Munda (2013) tentang pengaruh konsentrasi dan lama demineralisasi pada pembuatan gelatin tulang ayam terhadap kuantitas dan kualitas gelatin, tersaji dalam Gambar 1. Kesimpulan yang diperoleh bahwa konsentrasi asam asetat berpengaruh nyata terhadap nilai $\mathrm{pH}$ dan viskositas sedangkan lama demineralisasi dan interaksi antara kedua faktor berpengaruh nyata terhadap nilai $\mathrm{pH}$ namun tidak berpengaruh nyata terhadap rendemen, kekuatan gel dan viskositas.

Pembuatan gelatin ceker ayam diawali dengan preparasi ceker ayam. Ceker ayam dicuci sampai bersih, kuku jari dipotong, pada jari tengah kulit bagian belakang diiris dengan pisau mulai dari pangkal atau lurus sampai pada pangakal jarinya. Kulit bagian pangkal dikupas $\pm 2 \mathrm{~cm}$ ke bawah lalu dijepit dengan tang. Bagian tulang yang sudah dikupas dijepit pula dengan tang, kemudian masingmasing dipegang dengan satu tangan. Ditarik dengan berlawanan arah dengan secepatnya sampai kulit pada ujung jari ikut terkelupas. Daging yang ikut bersama kulit dihilangkan dengan pisau (Rares et al., 2017).

Proses pembuatan gelatin secara asam dengan menggunakan larutan asam asetat $\left(\mathrm{CH}_{3} \mathrm{COOH}\right)$ menurut metode yang dilakukan oleh Said et al. (2011a); Sompie et al. (2015) adalah sebagai berikut : ceker ayam dicuci pada air mengalir, direndam dalam air hangat selama 30 menit untuk menghilangkan sisik. Selanjutnya dicuci dan dipotong ukuran 1-2 $\mathrm{cm}^{2}$. Perbandingan ceker ayam dengan larutan perendaman adalah $1: 2$ untuk masing-masing perlakuan. Setelah direndam, kemudian dicuci dengan air mengalir berulang kali sampai $\mathrm{pH}$ netral. Selanjutnya kulit hasil rendaman diekstraksi dalam waterbath dengan suhu $60^{\circ} \mathrm{C}$ selama 5 jam. Proses selanjutnya penyaringan larutan gelatin menggunakan kertas saring. Larutan gelatin yang telah disaring dalam gelas ukur, ditutup dan dimasukan dalam oven dengan suhu $60^{\circ} \mathrm{C}$ untuk proses pemekatan selama 12 jam. Kemudian proses selanjutnya larutan gelatin dituang ke dalam wadah, kemudian dikeringkan dalam oven suhu $60^{\circ} \mathrm{C}$ selama 48 jam. Lembaran gelatin yang 
diperoleh kemudian dihaluskan dengan menggunakan blender dan disimpan (Rares et al., 2017).

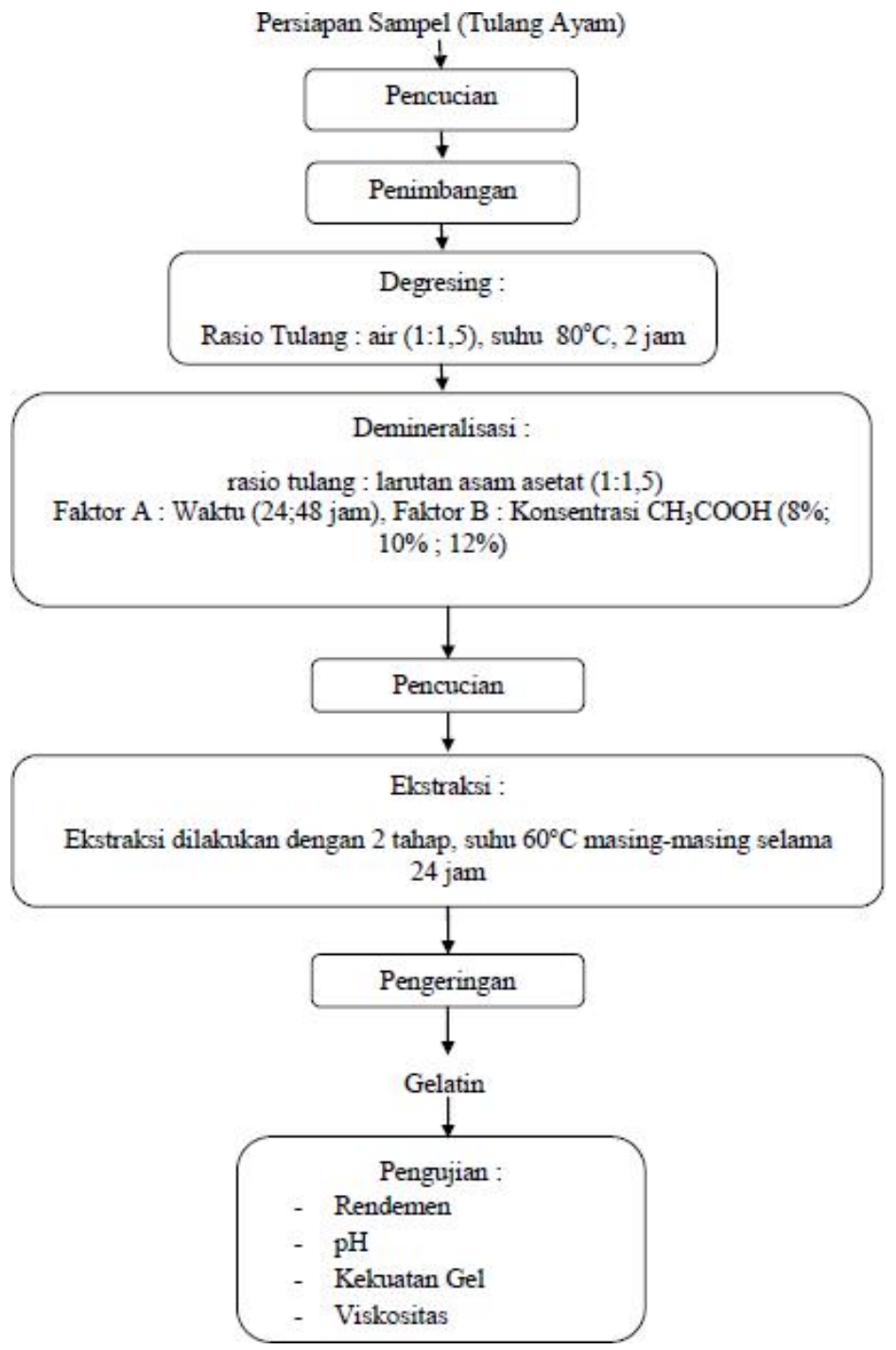

Gambar 1. Diagram alur prosedur pembuatan gelatin tulang ayam

(Munda, 2013) 


\section{BAB III \\ METODE PENELITAN}

a. Metode Penulisan

Penulisan ini menggunakan metode deskriptif. Penelitian deskriptif adalah salah satu jenis metode penelitian yang berusaha menggambarkan dan menginterpretasi objek sesuai dengan apa adanya. Metode deskriptif, data yang dikumpulkan berupa kata-kata (wawancara), sampling produksi, dan data stastistik sehingga mempermudah penulis untuk membuat hubungan antar obyek kajian.

b. Instrumen Penulisan

Penulisan ini, penulis menggunakan beberapa instrumen penulisan sebagai berikut.

1. Kajian literatur adalah instrumen yang digunakan untuk memperoleh data tambahan (sekunder). Data sekunder digunakan sebagai pelengkap data primer. Kajian literatur dapat diperoleh dari majalah ilmiah, bukubuku, dan internet.

2. Observasi: adalah instrumen yang dilakukan melalui pencatatan secara sistematis dengan melihat atau mengamati suatu objek.

3. Wawancara: adalah instrumen yang digunakan untuk menggali data tentang berbagai pandangan berikut fenomena yang melatari pandangan itu dari berbagai aspek, sesuai dengan ruang dan waktu subyek.

c. Kerangka Berpikir

Manfaat gelatin bagi produk pangan maupun non pangan banyak, namun masih $100 \%$ import serta tingkat kehalalannya masih diragukan sehingga kesejahteraan masyarakat kurang dalam hal pangan khususnya gelatin. Di sisi lain populasi ayam pedaging di Indonesia tinggi sehingga hasil ikutan pemotongan ayam khususnya ceker ayam juga besar. Ceker ayam berpotensi menjadi sumber gelatin. Potensi produksi gelatin ceker ayam dapat meningkatkan kesejahteraan 
masyarakat Indonesia. Berdasarkan uraian di atas, maka kerangka berpikir dalam penulisan studi ini disajikan pada Gambar 2.

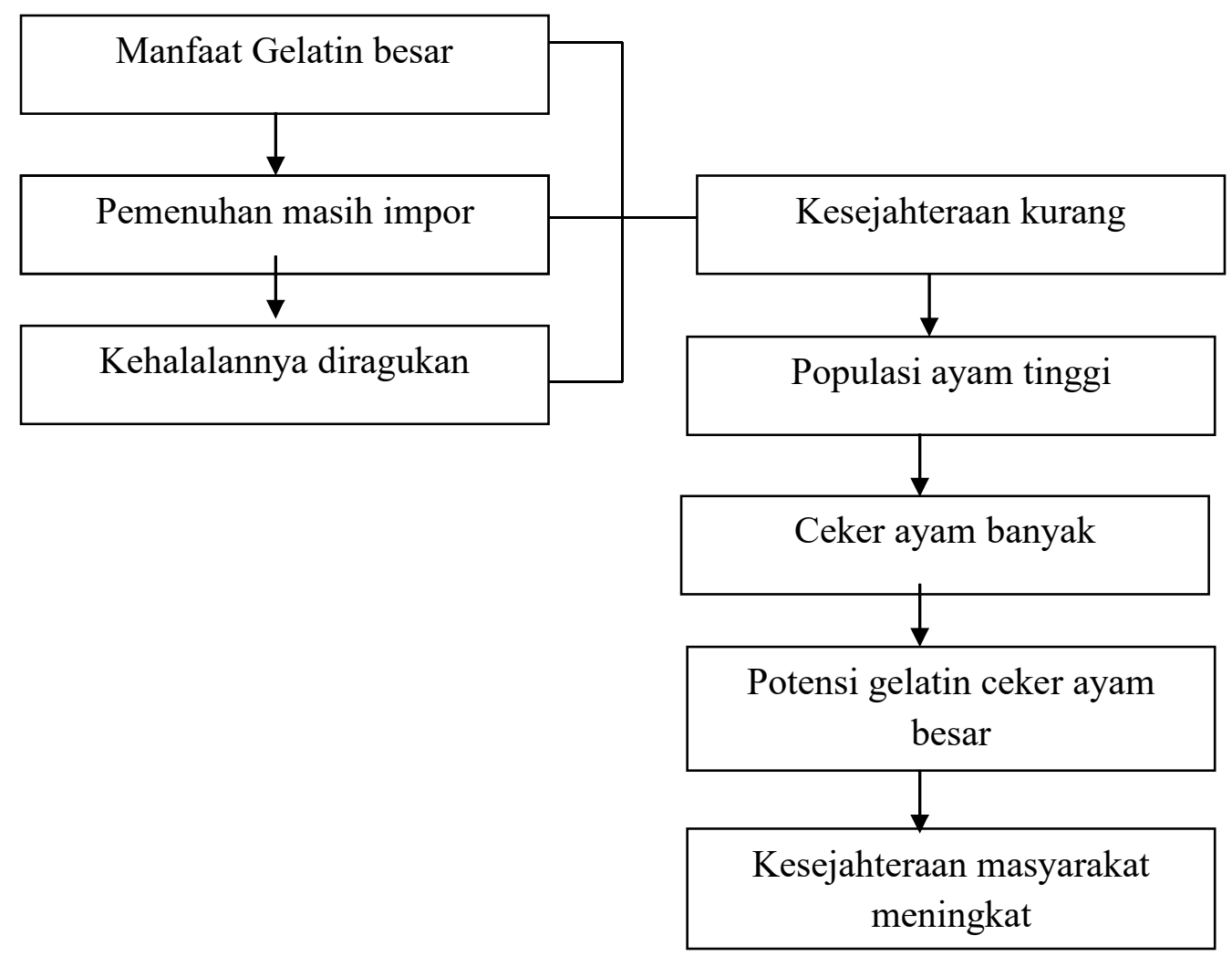

Gambar 2. Kerangka berpikir 


\section{BAB IV \\ PEMBAHASAN}

a. Gelatin di Indonesia

Penggunaan gelatin yang beragam tidak diimbangi dengan tumbuhnya produksi gelatin dalam negeri sehingga kebutuhan dalam negeri terhadap gelatin dipenuhi dengan cara impor. Tabel 2 adalah data impor gelatin dari tahun 2005 sampai 2007, 2010 hingga Februari 2014 disajikan pada Tabel 3.

Tabel 3. Jumlah impor gelatin indonesia

\begin{tabular}{clll}
\hline No & Tahun & Impor Gelatin $(\mathrm{kg})$ & Nilai (Rupiah) \\
\hline 1 & $2005^{1}$ & 596.933 & 17,2 milyar \\
2 & $2006^{1}$ & 1.094 .195 & 27,9 milyar \\
3 & $2007^{1}$ & 2.115 .741 & 86,6 milyar \\
4 & $2010^{2}$ & 3.149 .776 & 143,5 milyar \\
5 & $2011^{2}$ & 3.567 .824 & 269,2 milyar \\
6 & $2012^{2}$ & 3.771 .040 & 249,3 milyar \\
7 & $2013^{2}$ & 3.872 .104 & 311,8 milyar \\
8 & Februari $2014^{2}$ & 601.681 & 56,7 milyar \\
\hline & & Sumber : ${ }^{1}$ Said et al. $(2011 \mathrm{~b}),{ }^{2}$ Anonim $(2017)$
\end{tabular}

Gelatin impor biasanya adalah produk hasil pengolahan tulang dan kulit hewan ternak seperti sapi, domba, dan babi. Namun, hal ini menjadi permasalahan di Indonesia yang mayoritas penduduknya beragama islam. Agama islam mengajarkan hukumnya haram mengkonsumsi produk mengandung zat yang berasal dari hewan babi. Sumber lain gelatin perlu dicari lebih lanjut sehingga dapat memenuhi kebutuhan dan juga memenuhi persyaratan, khususnya terkait kehalalannya. Tingginya kebutuhan gelatin inilah merupakan sumber kesempatan yang baik untuk usaha mandiri gelatin dalam negeri.

Perlu diketahui bahwa faktor ketersediaan selama ini berdasarkan pada kemudahan pengadaan dan nilai ekonomis menyebabkan sebagian besar gelatin yang beredar selama ini berasal dari impor dan mayoritas bahan baku berasal dari babi. Sebagai gambaran, Hastuti (2007) menyatakan bahwa konsumsi rata-rata daging di Jerman adalah $60 \mathrm{~kg} / \mathrm{kapita} /$ tahun, dimana daging babinya adalah $40 \mathrm{~kg}$ artinya sekitar 2/3 konsumsinya adalah daging babi. Dengan demikian jika Jerman dapat menghasilkan daging sekitar 6-7 juta ton per tahun, berapa ketersediaan kulit babi sebagai bahan baku gelatin tersebut, belum lagi dari negara/benua lain. 
Pengenalan gelatin kepada masyarakat Indonesia sangat penting, karena penggunaan gelatin dewasa ini luas dan banyak sekali, bukan saja terbatas pada produk pangan tetapi juga pada produk non pangan seperti kapsul obat-obatan, kosmetika, film, dan kedokteran. Di Indonesia, gelatin masih merupakan barang impor, dimana negara pengimpor utama adalah Eropa dan Amerika. Secara umum dimanfaatan dalam industri pangan dan farmasi. Industri farmasi menggunakan gelatin sebagai bahan pembuat kapsul dan juga sekarang marak digunakan dalam industri pangan.

Gelatin tulang dan kulit yang beredar selama ini masih diragukan kehalalannya baik dari jenisnya seperti babi atau proses penyembelihan yang tidak menyebut Asma Allah dan memotong tidak melalui urat leher. Kebutuhan gelatin dalam negeri pun selama ini mayoritas masih mengimpor. Impor gelatin sejak tahun 2000 terus meningkat dan pada tahun 2003 telah mencapai 6.233 ton dengan nilai Rp. 69.622.370.000,-. Negara pemasok gelatin ke Indonesia tiga terbesar adalah China (3.877 ton), Jepang (969 ton) dan Perancis (278 ton) (Junianto et al., 2006). Kajian ini dapat memberikan masukan serta solusi bagi negara Indonesia untuk dapat memproduksi gelatin Indonesia dan gelatin halal untuk memenuhi kebutuhan masyarakat yang mayoritas penduduknya adalah muslim.

\section{b. Potensi Ceker Ayam sebagai Bahan Baku Gelatin}

Gelatin merupakan suatu jenis protein yang diekstrak dari jaringan kolagen atau ligamen (jaringan ikat) hewan. Gelatin yang dihasilkan ini dapat dimanfaatkan pada berbagai industri pangan ataupun non pangan, yaitu sebagai pengental, pengemulsi dan penstabil emulsi. Namun, suplai gelatin dalam negeri masih mengandalkan gelatin impor.

Ketergantungan akan gelatin impor harus dicarikan solusi alternatif, salah satu solusi alternatif yaitu dengan memanfaatkan bahan baku lokal sebagai bahan baku gelatin. Indonesia memiliki beragam bahan baku yang dapat dipergunakan dalam rangka produksi gelatin, diantaranya yaitu hasil ikutan industri pemotongan ternak yang selama ini belum dimanfaatkan secara optimal. By-product ternak berupa ceker ayam sebagai sumber bahan baku yang sangat berlimpah, sehingga 
bisa menjadi bahan baku lokal yang ketersediaanya mudah untuk didapatkan. Potensi ceker ayam sebagai sumber gelatin dapat dilihat dari semakin meningkatnya jumlah populasi ternak ayam di Indonesia.

Ceker ayam memiliki potensi yang besar untuk dijadikan sebagai sumber gelatin karena kandungan kolagen yang dimiliki yaitu sekitar 9\%. Kolagen ceker ayam banyak mengandung asam amino glycine, asam glutamic, proline dan hydroxyproline (Liu et al., 2011; Hashim et al., 2014). Banyak penelitian yang telah dilakukan mengenai gelatin dari ceker ayam. Ceker ayam yang diolah menjadi gelatin akan meningkatkan nilai guna maupun nilai jual.

Menghitung potensi ceker ayam yang diproduksi menjadi gelatin dapat dilihat dari produksi ceker dan hasil rendemen yang dihasilkan dari ceker ayam. Rendemen gelatin merupakan jumlah gelatin kering ( $d r y$ gelatin) yang dihasilkan dari sejumlah bahan baku kulit dalam keadaan bersih melalui proses ekstraksi. Beberapa nilai rendemen dari ceker ayam berkisar antara 7 sampai $12 \%$.

\section{c. Gelatin Ceker Ayam di Indonesia}

Pada umumnya gelatin berbahan baku kulit maupun tulang dan kulit dari ternak ruminansia. Tulang dan kulit merupakan hasil ikutan pemotongan ternak memiliki kandungan kolagen sehingga dapat diolah menjadi gelatin. Gelatin ceker ayam di Indonesi belum terlalu populer bagi kalangan masyarakat luas. Namun, telah banyak penelitian tentang pemanfaatan ceker ayam menjadi gelatin.

Penelitian Abustam et al. (2008) tentang penggunaan pelarut yang berbeda menunjukkan hasil yang nyata terhadap rendemen gelatin. Lebih lanjut Siregar et al. (2015) meneliti tentang penggunaan pelarut yang berbeda. Hasil menunjukkan pelarut asam sulfat menghasilkan persentase rendemen tertinggi dibandingkan pelarut yang lain karena kemampuan asam sulfat dalam menghidrolisis heliks kolagen untuk menjadi gelatin lebih efektif dibandingkan pelarut lain. Nilai rendemen dengan asam asetat $4,45 \%$ asam klorida $6,62 \%$ asam sulfat $7,47 \%$.

Selain pelarut suhu saat ekstraksi juga mempenaruhi hasil dari gelatin. Gelatin yang notabene adalah protein akan rentan terhadap suhu yang tinggi. Lebih lanjut perbedaan suhu ekstraksi diteliti oleh Sompie et al. (2015), gelatin kulit kaki ayam yang diproduksi menggunakan suhu ekstraksi $50^{\circ} \mathrm{C}, 55^{\circ} \mathrm{C}$, dan 
$60^{\circ} \mathrm{C}$ menghasilkan karakteristik gelatin dengan kualitas yang baik karena masih memenuhi standar yang ditetapkan SNI.

Penelitian Puspitasari et al. (2013) menunjukan bahwa perendaman dengan menggunakan 2-5\% $\mathrm{HCl}$ selama 24-48 jam mempengaruhi rendemen gelatin tulang ceker ayam sebanyak 0,38-3,25\%. Gelatin yang dihasilkan dari perendaman $\mathrm{HCl}$ 5\% selama 48 jam merupakan gelatin terbaik dan sesuai dengan standar GMIA (2012) dengan $\mathrm{pH}$ 4, viskositas 3,03 cP dan gel strength sebesar 422,2 bloom. Penelitian terbaru Rares et al. (2017) dengan waktu perendaman yang berbeda mempengaruhi rendemen gelatin yaitu dengan waktu 12 jam, 24 jam, 36 jam, dan 48 jam berturut-turut sebesar 10,7\%; 10,25\%; 11,89\%; dan 11,2\%. Waktu yang efisien dalam proses perendaman adalah 12 jam, dengan waktu 12 jam hasilnya tidak jauh berbeda dengan 36 jam.

Berdasarkan penelitian-penelitian yang telah dilakukan, ceker ayam memiliki potensi yang besar sebagai bahan baku gelatin. Pemanfaatan ceker ayam perlu dioptimalkan dengan menjadikannya sebagai bahan baku gelatin. Aplikasi penelitian dalam bidang industri produksi gelatin ceker ayam perlu diterapkan melihat potensinya yang besar sehingga gelatin ceker ayam menjadi lebih populer di masyarakat Indonesia.

\section{d. Potensi Industri Gelatin Ceker Ayam di Indonesia}

Pengolahan gelatin dari ceker dapat dimaksimalkan dengan cara mengaplikasikan beberapa penelitian yang telah dilakukan. Penelitian tersebut menggunakan beberapa metode yang berbeda dalam memproduksi gelatin. Oleh karena itu, metode terbaik dapat menjadikan rujukan dalam memproduksi gelatin. Rendemen gelatin yang dihasilkan dalam penelitian Rares et al. (2017) berkisar antara 10,7-11,89\% dan persentase rendemen gelatin tersebut tidak jauh berbeda dengan nilai rendemen gelatin yang diproduksi dari kulit kambing yaitu 5,17 6,24\% (Said et al., 2011a), dan rendemen dari tulang/kulit kaki ayam pada penelitian Miskah et al. (2010) adalah 7,96\%.

Pemenuhan kebutuhan gelatin dalam negeri dapat diperkirakan dengan melihat potensi bahan baku yang ada. Jumlah populasi ternak ayam ras pedaging setiap tahunnya cukup besar yaitu sebanyak 1.592.669.402 ekor. Asumsi bahwa 
bobot potong 1,5 kg sementara presentase ceker sekitar 4,57\% (Nita et al., 2015), dan rendemen sekitar 10,7\% (Rares et al., 2017) maka dapat diketahui jumlah gelatin yang dapat diproduksi. Karena rendemen setiap jenis ternak telah diketahui maka Indonesia memiliki potensi produksi gelatin sebesar $11.681 .991,16 \mathrm{~kg}$, bila konversi dalam rupiah maka mencapai nilai Rp.1.168.199.116.000. Dengan asumsi harga perkilogram Rp. 100.000. Perhitungan lengkap dapat dilihat pada Lampiran 1.

Apabila dilihat dari kebutuhan gelatin di Indonesia setiap tahunnya hanya sekitar 4 ribu ton saja sehingga potensi pemenuhan gelatin cukup besar. Hanya perlu memerlukan 34\% ceker ayam dari ayam yang dipotong telah dapat memenuhi kebutuhan nasional apabila $100 \%$ produksi ceker ayam digunakan untuk produksi gelatin. Hal ini menunjukkan bahwa Indonesia dapat mencukupi kebutuhan gelatin dalam negeri bahkan dapat diekspor.

Dengan memanfaatkan potensi ceker ayam menjadi bahan baku produksi gelatin karena pertimbangan untuk mengurangi impor dan keraguan kehalalan yang dapat mengakibatkan ketergantungan. Disisi lain, jumlah ternak ayam yang dipotong setiap tahunnya meningkat dan menghasilkan hasil ikutan pemotongan ternak terutama ceker yang belum dimanfaatkan secara optimal. Oleh karena itu, maka Indonesia memiliki potensi yang besar dalam memproduksi gelatin. Pengolahan ceker ayam menjadi gelatin dapat digunakan sebagai alternatif utama dalam mengoptimalkan hasil ikutan pemotongan ternak terutama ceker ayam sebagai upaya memenuhi kebutuhan gelatin dalam negeri dengan melihat potensi bahan baku berupa ceker ayam. Masyarakat diharapkan dapat memproduksi gelatin sebagai upaya meningkatkan kesejahteraan dan memenuhi gelatin lokal di Indonesia. 


\section{BAB V}

PENUTUP

a. Kesimpulan

Potensi produksi gelatin di Indonesia besar dengan melihat produksi ceker yang melimpah di dalam negeri. Pengolahan ceker ayam menjadi gelatin dapat menjadi alternatif utama dalam pengolahan hasil ikutan terutama ceker ayam. Oleh karena itu impor dapat dikurangi, keraguan akan kehalalan produk dapat hilang, dan masyarakat dapat menciptakan peluang pekerjaan dalam memproduksi gelatin.

b. Saran

Hendaknya dilakukan kajian lebih lanjut terkait industri pembuatan gelatin halal di Indonesia. Semoga kedepan dapat dilakukan kajian yang lebih mendalam tentang efisiensi pembuatan gelatin dari ceker ayam. 


\section{DAFTAR PUSTAKA}

Abustam, E., H.M. Ali, M. I. Said dan J. C. Likadja. 2008. Sifat Fisik Gelatin Kulit Kaki Ayam Melalui Proses Denaturasi Asam, Alkali dan Enzim. Seminar Nasional Teknologi Peternakan dan Veteriner. Tersedia pada: http://peternakan.litbang.pertanian.go.id/fullteks/semnas/pro08112.pdf?secure=1. Diakses pada: 13.42 on 9 Oktober 2017 .

Amiruddin, M. 2007 Pembuatan dan Analisis Karakteristik Gelatin dari Tulang Ikan Tuna (Thumus albacareas). Skripsi. Institut Pertanian Bogor. Bogor.

Anonim. 2017. Pendahuluan. Tersedia pada: https://eprints.uns.ac.id/22974/1/ H0910005_bab1.pdf. Diakses pada: 11.30 on 7 September 2017.

Barbooti, M. M., S. R. Raouf, H. Firas dan K. Al-Hamdani. 2008. Optimization of production of food grade gelatin from bovine hide wastes. Eng.Tech. 26 (2): $240-253$.

Bosch, E.V.D. dan C. Geielens. 2003. Gelatin degradation at elevated temperature. International Journal of Biological Macromolecules. 32 (3-5): 129-138.

Direktorat Jenderal Peternakan dan Kesehatan Hewan 2014. Data Statistik

Kemaritiman dan Sumber Daya Alam. Tersedia pada: https://www.bappenas.go.id/id/data-dan-informasi-utama/data-danstatistik1/sumber-daya-alam-dan-lingkungan-hidup/. Diakses pada: 30 Agustus 2017.

Djabourov, M., J. Lechaire, dan F. Gaill. 1993. Structure and rheology of gelatin and collagen gels. Jurnal Biorhelogy. 30 (3-4): 191-205.

GME. 2015. Gelatine.org Market Data 2011. Gelatine Manufacture of Europe. http://www.gelatine.org/en/gelatine/history/html.

GMIA. 2012. Standart Methods For The Testing of Edible Gelatin. Offical Procedure of The Gelatin Manufacturers Institute of America. America.

Gómez-Guillén, M.C., B. Giménez, M.E. López-Caballero dan M.P. Montero. 2011. Functional And Bioactive Properties Of Collagen And Gelatin From Alternative Sources: a Review.

Hashim, P., M. S. Mohd Ridzwan, J. Bakar. 2014. Isolation and characterization of collagen from chicken feet. Journal of Biological, Biomolecular, Agricultural, Food and Biotechnological Engineering 8(3): 250-254.

Hastuti, D. 2007. Pengenalan dan proses pembuatan gelatin. Mediagro. 3(1): 3948.

Junianto, K. Haetami dan I. Maulina. 2006. Produksi Gelatin dari Tulang Ikan dan Pemanfaatannya sebagai Bahan Dasar Pembuatan Cangkang Kapsul. Fakultas Perikanan dan Ilmu Kelautan Universitas Padjadjaran, Bandung. 
Liu, D. C., Y. K. Lin, dan M. T. Chen. 2001. Optimum condition of extracting collagen from chicken feet and its characteristics. Asian-Australasian Journal of Animal Sciences 14(11): 1638-1644.

Manjula, U. D. P., S. C. Jayamanne dan G. G. N. Thushari. 2015. Effect of pretreatment on physical properties of yellow fin tuna (Thunnus albacares) fish glue. International Journal of Fisheries and Aquatic Studies 2(4S): 1421.

Miskah, S., I. M. Rahmadianti dan A.F. Hanif. 2010. Pengaruh konsentrasi $\mathrm{CH}_{3} \mathrm{COOH} \% \mathrm{HCl}$ sebagai pelarut dan waktu perendaman pada pembuatan gelatin berbahan baku tulang/kulit kaki ayam. Jurnal Teknik Kimia (1) 17: 1-6.

Montero P. dan M.C. Gómez-Guillén. 2000. Extracting conditions for megrim (Lepidorhombus boscii) skin collagen affect functional properties of the resultant gelatine. Jurnal Food Sci 65 (3): 434-438.

Munda, M. 2013. Pengaruh Konsentrasi Asam Asetat Dan Lama Demineralisasi Terhadap Kuantitas Dan Kualitas Gelatin Tulang Ayam. Skripsi. Fakultas Peternakan Universitas Hasanuddin. Makassar.

Nik Aisyah N. M., Nurul H, Azhar M. E. dan Fazilah A. 2014. Poultry as an alternative source of gelatin. Health and the Environment Journal 5(1): 3749.

Ockerman H.W dan C.L. Hansen. 2000. Animal By Product Processing and Utilization. CRC Press. USA.

Peraturan Pemerintah Nomor 68. 2002. Ketahanan Pangan. Tersedia pada: http://bkp.pertanian.go.id/statis-17-peraturan.html. Di akses pada: 11. 32 on 3 Oktober 2017.

Puspitasari, D. A. P., V. P. Bintoro Dan B. E. Setiani. 2013. Sifat- sifat gel gelatin tulang cakar ayam. Jurnal Pangan dan Gizi 4 (7):19-28.

Rahman, M. N. A. dan S. A. S. K. A. Jamalulail. 2012. Extractions, Physicochemical Characterizations and Sensory Quality Of Chicken Feet Gelatin. Borneo Science. Tersedia pada: https://www.tcithaijo.org/index.php/fabjournal/article/download/ 77404/62091. Diakses pada: 11.32 on 9 September 2017.

Rares, R. C., M. Sompie, A. D. Mirah, dan J. A.D. Kalele. 2017. Pengaruh waktu perendaman dalam larutan asam asetat $\left(\mathrm{CH}_{3} \mathrm{COOH}\right)$ terhadap karakteristik fisik dan kimia gelatin ceker ayam. Jurnal Zootek ("Zootek” Journal ) 37 (2) : $268-275$.

Said, M. I., J. C. Likadja dan M. Hatta. 2011a. Pengaruh waktu dan konsentrasi bahan curing terhadap kuantitas dan kualitas gelatin kulit kambing yang diproduksi melalui proses asam. Jitp 1(2):119-128.

Said, M.I., S. Triatmojo, Y. Erwanto dan A. Fudholi. 2011b. Karakteristik gelatin kulit kambing yang diproduksi melalui proses asam dan basa. Jurnal Agritech 3 (3): 190-200. 
Saleh, e. 2004. Teknologi Pengolahan Susu Dan Hasil Ikutan Ternak. Program Studi Produksi Ternak. Fakultas Pertanian. Universitas Sumatera Utara.

Siregar, H., S. Ginting, dan L. N. Limbong. 2015. Pengaruh jenis pelarut dan suhu ekstraksi kaki ayam terhadap karakteristik fisik dan kimia gelatin yang dihasilkan. J.Rekayasa Pangan dan Pert. 3(2): 171-177.

Sompie, M., A. D. Mirah, dan Linda Ch. M. Karisoh. 2015. Pengaruh perbedaan suhu ekstraksi terhadap karakteristik gelatin kulit kaki ayam. Pros Sem Nas Masy Biodiv Indon. 1(4): 792-795.

Taufik M. 2011. Kajian Potensi Kulit Kaki Ayam Broiler sebagai Bahan Baku Gelatin dan Aplikasinya dalam Edible Film Antibakteri. [Disertasi]. Fakultas Peternakan Universitas Gadjah Mada, Yogyakarta.

Undang-Undang Nomor 11. 2009. Kesejahteraan Sosial. Tersedia pada: https://luk.staff.ugm.ac.id/atur/sehat/UU-11-2009KesejahteraanSosial.pdf. Diakses pada: 10.32 on 29 Oktober 2017.

Widyasari, R. dan S. Rawdkuen. 2014. Extraction and characterization of gelatin from chicken feet by acid and ultrasound assisted extraction. Food and Applied Bioscience Journal 2 (1): 85-97. 
